\title{
Relative growth of Uca burgersi (Crustacea, Ocypodidae) from two mangroves in the southeastern Brazilian coast
}

\author{
Aline Staskowian Benetti \& Maria Lucia Negreiros-Fransozo
}

Núcleo de Estudos em Biologia, Ecologia e Cultivo de Crustáceos (NEBECC), Departamento de Zoologia, Instituto de Biociências, Universidade Estadual Paulista (UNESP), Caixa Postal 510, 18618-000 Botucatu, São Paulo, Brasil. (mlnf@ibb.unesp.br)

\begin{abstract}
The relative growth of the fiddler crab Uca burgersi Holthuis, 1967 was analyzed in two populations from different mangroves (Ubatumirim and Cavalo rivers) in the southeastern Brazilian coast, monthly sampled from May, 2001 to April, 2002. The population from a high productivity level mangrove reaches the sexual maturity in larger sizes than the population from a less productive site. This results can be attributed to the greater amount of nutrients found in the Cavalo than in Ubatumirim mangrove.
\end{abstract}

KEYWORDS. Relative growth, Uca, size maturity, mangrove.

\section{INTRODUCTION}

The existence of a hard exoskeleton in Crustaceans limits their growth, thus the body dimensions in such organisms remain constant in the intermoult period. Some structures grow in distinct proportions to each other, which allow to observe differences in the growth rate when two body dimensions are compared (HARTNOLL, 1974). The extensive literature on the relative growth of brachyuran crabs presents the theorical basis on allometry (HARTNOLL, 1982; HuXLEY \& RichaRdS, 1931; Teissier, 1933, 1960; Weymouth \& Mackay, 1936), beyond some aspects related to the determination of size at onset of sexual maturity (WeYMOUTH \& MACKAY, 1934; Gore \& Sсотто, 1983). The great number of papers developed about brachyurans relative growth are probably due to the possibility of estimating the sexual maturity in crabs, that is very useful, particularly, in the species of economic interest (Lewis, 1977; PINHEIRO \& Fransozo, 1993; Mantelatto \& Fransozo, 1994; Santos et al., 1995). The relative growth patterns are also indicative of sexual dimorphism, and it can be used for developmental phasis prediction in crabs. The secondary sexual characters (shape and size of chelipeds, abdomen and pleopods) present differential growth rates before and after the maturation life phasis (HARTNOLL, 1974, 1978, 1982, 1985; VANNINI \& GHERARDI, 1988). For brachyurans, the knowledge on the relative growth during the juvenile phasis is scarce, because of the difficult identification of the specimens in the natural environment and the low survival rate of the larvae until the juvenile phases in laboratory (NEGREIROS-FrANSOZO \& FransOZO, 1991).

The fiddler crab Uca burgersi Holthuis, 1967 is distributed along the Western Atlantic from Florida, Mexico Gulf, Antilles and Venezuela to Brazil (from Maranhão to São Paulo States). This species burrows in the sediments of beaches, lagoons and estuaries, usually near mangrove trees (Melo, 1996). GiBBS \& BRYAN (1972) performed the study of strontium, magnesium and calcium in the environment in which $U$. burgersi lives, and they also studied the association of these elements with the exoskeleton. Ecological studies were performed by GiBBs (1974) from Barbuda, Leeward Island and also by THURMAN II (1987), from east of Mexico.

The aim is to describe the relative growth of $U$. burgersi and its size at onset of sexual maturity based in populations from two mangroves in the São Paulo State northern coast.

\section{MATERIAL AND METHODS}

Crabs were monthly sampled from May, 2001 to April, 2002 in the mangroves of Ubatumirim river $\left(23^{\circ} 20^{\prime} 17.8^{\prime \prime} \mathrm{S}, 44^{\circ} 53^{\prime} 2.2^{\prime \prime} \mathrm{W}\right)$ and Cavalo river $\left(23^{\circ} 243^{\prime \prime} \mathrm{S}\right.$, $45^{\circ} 0073$ ” W) in the Ubatuba municipality, São Paulo, Brazil (fig. 1). The mangrove of Cavalo river is monospecific

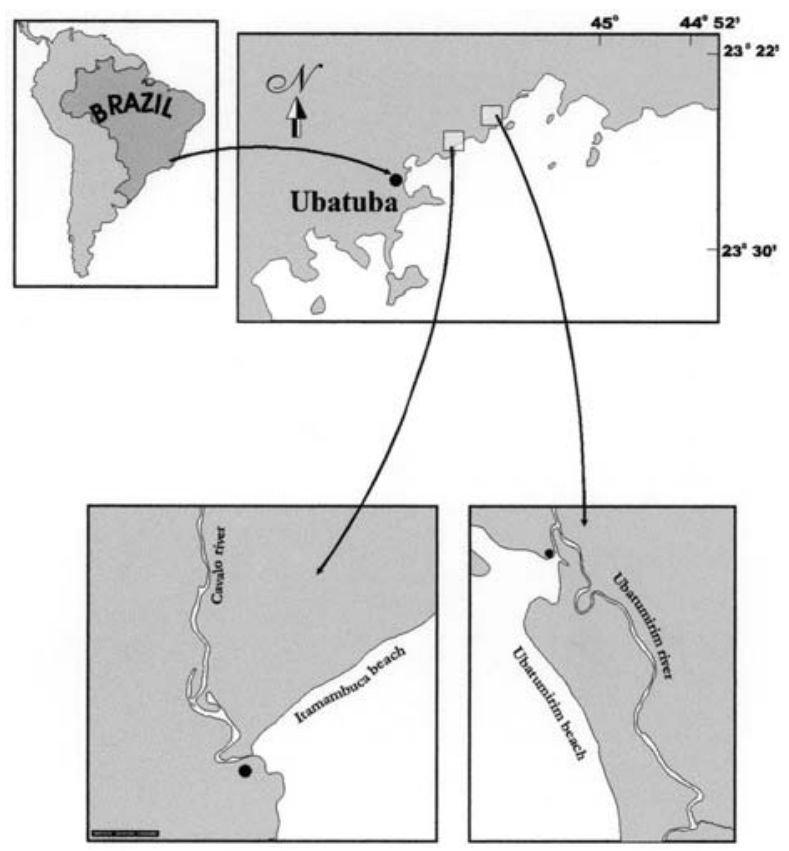

Fig. 1. Localization of the study sites $(\bullet)$ in the mangroves of Ubatumirim river and Cavalo river, Ubatuba, São Paulo, Brazil. 
concerning its arboreal composition. Laguncularia racemosa (L.) is the only one typical mangle tree in such place. The median density of trees registered by CoLPO \& Negreiros-Fransozo (2003) was 1,250 ind./ha and the median height was $4.8 \mathrm{~m}$. In the Ubatumirim river it was recorded L. racemosa and Avicennia shaueriana Stapf. \& Leech. by NEGREIROS-FrANSOZO (2002). In this later site, the median value of density was 6,250 ind./ha and the median height was $10.6 \mathrm{~m}$.

Sediment samples from both study sites, in each year season, were collected in order to analyze the organic matter. The samples were dried at $60^{\circ} \mathrm{C}$ until to attain constant weight. After that, they were submitted for a period of 3 hours at $500^{\circ} \mathrm{C}$, and the samples were then weighed again. The organic matter content of sediment samples was determined by ash-free dry weighing.

The crabs were captured during low tide by two collectors excavating the substratum during $30 \mathrm{~min}$, using the capture effort per unit technique. The sampled area comprised approximately 0.1 ha. Crabs were put in plastic labeled bags, and frozen. In the laboratory, crabs were unfrozen and the sex was identified. Some specimens are deposited in the NEBECC collection (UNESP), Botucatu.

The following measurements were performed for both sexes (fig. 2): carapace width (CW) and length (CL); abdomen width (AW) obtained from the $5^{\text {th }}$ to $6^{\text {th }}$ abdominal somite. For males, the length (PL) and the height $(\mathrm{PH})$ of the major cheliped propodus and the gonopod length (GL) were also measured. For females, the length (GL) and the height $(\mathrm{PH})$ of the right cheliped were measured. The dimensions were taken with a precision caliper $(0.01 \mathrm{~mm})$. Only crabs in intermoult stages and complete, without any defective appendages, were used in this analysis.

The data were plotted and the point dispersion for each regression was analyzed. The data were adjusted to a power function $\mathrm{Y}=\mathrm{aX}^{\mathrm{b}}$ (HuXLEY, 1950), being $\mathrm{CL}=$ independent variable (x) and other dimensions the dependent variable (y); b is the allometric constant, that expresses the allometry degree of the body part in study. When $b>1$ the growth was allometric positive, when $b<1$, the growth was allometric negative and when $b=1$, the growth was isometric. The b value was tested by a tStudent test at $5 \%$ of significance level. In order to determine the size at onset of sexual maturity for each sex, the software Mature II (SOMERTON, 1980) was used as there was no overlapping of the curves in both sexes and sites.

The dispersion point for juvenile and adult crabs were sorted according to the obtained results of Mature II and the data logarithmized. The linear equation obtained is represented by $\log y=\log a+b \log x$, where $b$ indicated the slope of the straight line and a, the intercept in the $\mathrm{Y}$ axis. The straight lines obtained were compared by covariance analysis (ZAR, 1996). The crabs were grouped in demographic categories for each locality as follows: juvenile males (JM), juvenile females (JF), adult males (AM), adult females (AF). The comparisons of the median size for each category were accomplished by means the Mann-Whitney test at $5 \%$ of significance level (SOKAL \& ROHLF, 1979).
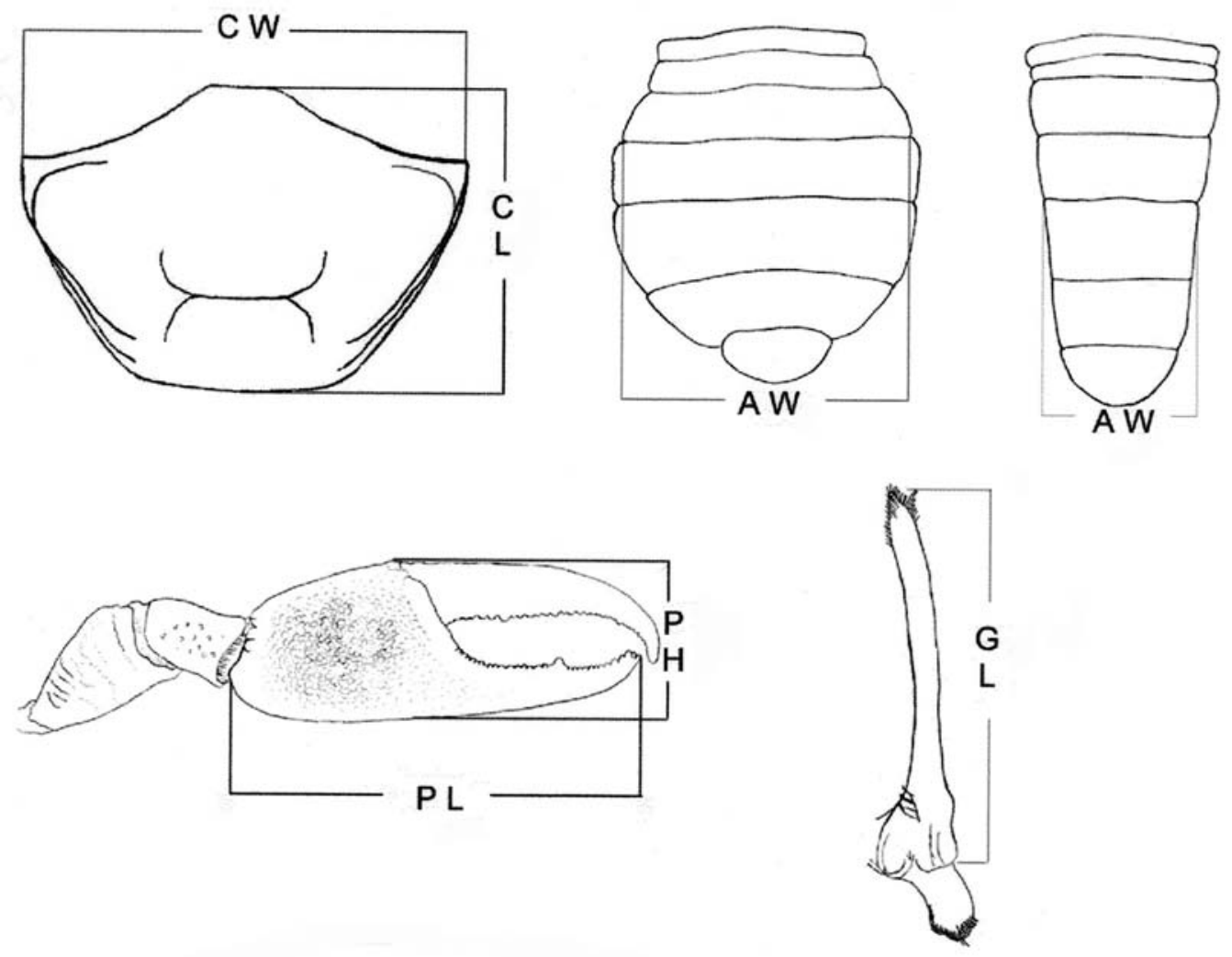

Fig. 2. Uca burgersi Holthuis, 1967, body parts measured (AW, abdomen width; CL, carapace length; CW, carapace width; GL, gonopod length; PH, propodus height; PL, propodus length). 


\section{RESULTS}

Considering each year-season, the organic matter content in the sediment of the Cavalo river mangrove $(5.11 \pm 0.5 \%)$ was higher than that obtained in the sediment of Ubatumirim river mangrove $(1.71 \pm 0.25 \%)$ (ANOVA, $\mathrm{p}<0.05)$.

A total of 630 fiddler crabs were used in the performed regressions for the Ubatumirim population, being 314 males and 316 females, while a total of 582 fiddler crabs, for the Cavalo population, being 315 males and 267 females. The median size of adult crabs from Cavalo population $(11.8 \mathrm{~mm} \mathrm{CW})$ was statistically larger than that from Ubatumirim $(11.0 \mathrm{~mm} \mathrm{CW})(\mathrm{p}<0.05)$, while the median size of the juvenile specimens did not differ between the two populations.

The morphometric relationships that best evidenced the beginning of the sexual maturity for $U$. burgersi were $\mathrm{CW} v s$. PL, for males and $\mathrm{CW} v s$. AW, for females (figs. 3, 4). In the Ubatumirim river, only the regressions $\mathrm{CW} v s$. AW, for males and $\mathrm{CW} v s$. PL and $\mathrm{CW}$ vs. $\mathrm{PH}$, for females, did not present significant differences between demographic categories and in the Cavalo river only the regressions CW vs. CL for males and CW vs. PL and CW vs. PH for females (tabs. I, II).

A positive allometric growth was observed in males to the dimensions PL, PH and GL in the Ubatumirim river population, while only PL showed a positive allometric growth for Cavalo river population. In females, the positive allometric growth was only observed for the abdominal width in both sites (tabs. I, II).

Males of $U$. burgersi from Ubatumirim mangrove reach their sexual maturity at $7.5 \mathrm{~mm}$ of $\mathrm{CW}$ and females at $6.2 \mathrm{~mm}$ (tab. I). In the Cavalo mangrove, males reach their sexual maturity at $8.8 \mathrm{~mm}$ of $\mathrm{CW}$ and females at 6.5 $\mathrm{mm}$ (tab. II).

\section{DISCUSSION}

Data on organic matter content in the sediment revealed a higher rate in the bottom of the Cavalo river mangrove than in Ubatumirim river mangrove, what can influence the fiddler crab growth. The fact of adult fiddler crabs to be larger in the population from Cavalo site than that from Ubatumirim site is probably related to their differential growth rate as in the former site the food resources are available (organic matter) in a higher quantity.

The $U$. burgersi population in the Cavalo river also achieves its sexual maturity in larger sizes than that from Ubatumirim river. The availability of food resources is one of the main factors that can regulate the size at sexual maturity (HINES, 1989). If one population lives in a richer environment concerning to food resources, their individuals probably grow without alimentary restriction compared with those from a severe environment with a low quantity or quality of food. Such growth can produce different sizes at onset of sexual maturity in decapods (Wenner et al., 1974). According to Colpo \& NegreirosFRANSOZO (2003), the mangrove of Cavalo river has a high amount of organic matter and nitrogen in the sediment, which constitute a good resource of available food for fiddler crabs.

During the development, brachyurans pass by several morphological changes, being the puberty molt, presenting remarkable changes related to sexual maturity
Ubatumirim river

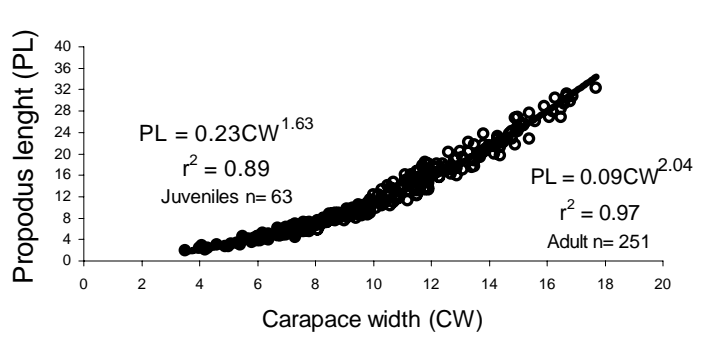

3

Ubatumirim river

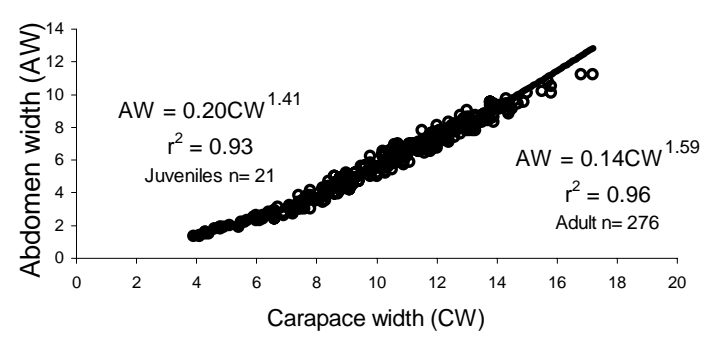

4
Cavalo river

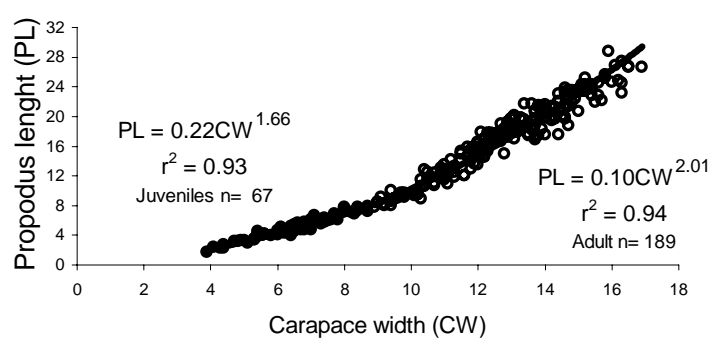

Cavalo river

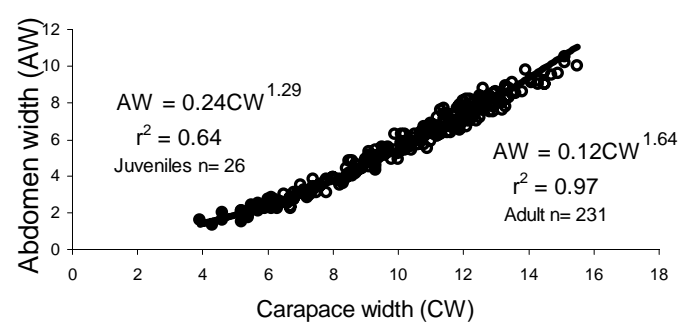

Figs. 3, 4. Uca burgersi Holthuis, 1967, juveniles and adult. Points dispersion fitted to a power function and equation obtained for the morphometric relationships: 3, males, PL vs. CW; 4, females, AW vs. CW. 
Table I. Result of the regressions analysis for the Uca burgersi population from Ubatumirim river (A, adult; a and b, constants; AW, abdomen width; allometry $=t$ test for slope (b); CL, carapace length; CW, carapace width; F, female; GL, gonopod length; J, juvenile; M, male; N, number of crabs; PH, propodus height; PL, propodus length; $\mathrm{r}^{2}$, determination coefficient; $\mathrm{t}$ and $\mathrm{F}$, statistic values; $\mathrm{x}$, independent variable; $\mathrm{y}$, dependent variable; 0 , isometry; -, negative allometry; +, positive allometry; *, significant for the $\mathrm{t}$-Student test, $\alpha=0.05$ ).

\begin{tabular}{|c|c|c|c|c|c|c|c|c|}
\hline \multirow{2}{*}{ Relationships } & \multirow[t]{2}{*}{ Sex } & \multirow{2}{*}{$\mathrm{N}$} & \multirow{2}{*}{$\begin{array}{l}\text { Linearized equation } \\
\log y=\log a+b \log x\end{array}$} & \multirow[t]{2}{*}{$r^{2}$} & \multirow{2}{*}{$\mathrm{t}(\mathrm{b}=1)$} & \multirow[t]{2}{*}{ Allometry } & \multicolumn{2}{|c|}{ Results of the Mature II } \\
\hline & & & & & & & Value $\mathrm{F}$ & Cut point \\
\hline \multirow{4}{*}{ CW vs. CL } & $\mathrm{J} \mathrm{M}$ & 65 & $\log C L=-0.159+1.023 \log C W$ & 0.935 & 0.59 & 0 & - & - \\
\hline & A M & 237 & $\log C L=-0.089+0.959 \log C W$ & 0.987 & $5.70^{*}$ & - & - & - \\
\hline & J F & 24 & $\log C L=-0.132+1.021 \log C W$ & 0.903 & 0.29 & 0 & - & - \\
\hline & A F & 292 & $\log C L=-0.113+0.994 \log C W$ & 0.968 & 0.41 & 0 & - & - \\
\hline \multirow{3}{*}{ CW vs. AW } & J/A M & 294 & $\log A W=-0.421+0.884 \log C W$ & 0.971 & $12.89^{*}$ & - & - & - \\
\hline & J F & 21 & $\log \mathrm{AW}=-0.706+1.407 \log \mathrm{CW}$ & 0.932 & $4.68^{*}$ & + & $3.03^{*}$ & $6.2 \mathrm{~mm}$ \\
\hline & A F & 276 & $\log A W=-0.857+1.591 \log C W$ & 0.965 & $32.24^{*}$ & + & - & - \\
\hline \multirow{3}{*}{ CW vs. PL } & $\mathrm{J} \mathrm{M}$ & 63 & $\operatorname{LogPL}=-0.648+1.629 \log C W$ & 0.885 & $8.37 *$ & + & $23.45^{*}$ & $7.5 \mathrm{~mm}$ \\
\hline & A M & 251 & $\operatorname{LogPL}=-1.013+2.043 \log C W$ & 0.970 & $46.03^{*}$ & + & - & - \\
\hline & $\mathrm{J} / \mathrm{A} \mathrm{F}$ & 309 & $\operatorname{LogPL}=-0.300+0.912 \log C W$ & 0.914 & 0.55 & 0 & - & - \\
\hline \multirow{3}{*}{$\mathrm{CW} v s . \mathrm{PH}$} & $\mathrm{J} \mathrm{M}$ & 64 & $\operatorname{LogPH}=-1.215+1.930 \log C W$ & 0.900 & $11.38^{*}$ & + & - & - \\
\hline & A M & 226 & $\operatorname{LogPH}=-0.898+1.577 \log C W$ & 0.971 & $31.84 *$ & + & - & - \\
\hline & $\mathrm{J} / \mathrm{A} \mathrm{F}$ & 309 & $\mathrm{LogPH}=-0.815+0.954 \log \mathrm{CW}$ & 0.936 & 0.32 & 0 & - & - \\
\hline \multirow{2}{*}{$\mathrm{CW} v s . \mathrm{GL}$} & $\mathrm{J} M$ & 65 & $\log G L=-0.862+1.554 \log C W$ & 0.820 & $6.03 *$ & + & - & - \\
\hline & A M & 236 & $\operatorname{LogGL}=-0.432+1.044 \log C W$ & 0.934 & $2.42 *$ & + & - & - \\
\hline
\end{tabular}

Table II. Result of the regressions analysis for the Uca burgersi population from Cavalo river (A, adult; a and b, constants; AW, abdomen width; allometry $=t$ test for slope (b); CL, carapace length; CW, carapace width; F, female; GL, gonopod length; J, juvenile; M, male; N, number of crabs; PH, propodus height; PL, propodus length; $\mathrm{r}^{2}$, determination coefficient; $t$ and $\mathrm{F}$, statistic values; $\mathrm{x}$, independent variable; $\mathrm{y}$, dependent variable; 0, isometry; -, negative allometry; +, positive allometry; *, significant for the t-Student test, $\alpha=0.05$ ).

\begin{tabular}{|c|c|c|c|c|c|c|c|c|}
\hline \multirow[t]{2}{*}{ Relationships } & \multirow[t]{2}{*}{ Sex } & \multirow[t]{2}{*}{$\mathrm{N}$} & \multirow{2}{*}{$\begin{array}{l}\text { Linearized equation } \\
\text { Logy }=\log a+b \log x\end{array}$} & \multirow[t]{2}{*}{$\mathrm{r}^{2}$} & \multirow[t]{2}{*}{$\mathrm{t}(\mathrm{b}=1)$} & \multirow[t]{2}{*}{ Allometry } & \multicolumn{2}{|c|}{ Results of the Mature II } \\
\hline & & & & & & & Value $\mathrm{F}$ & Cut point \\
\hline \multirow{3}{*}{$\mathrm{CW} v s . \mathrm{CL}$} & $\mathrm{J} / \mathrm{A} \mathrm{M}$ & 257 & $\log C L=-0.097+0.962 \log C W$ & 0.991 & $6.33^{*}$ & - & - & - \\
\hline & $\mathrm{J} F$ & 33 & $\log C L=-0.024+0.860 \log C W$ & 0.680 & 1.32 & 0 & - & - \\
\hline & A F & 200 & $\log C L=-0.127+1.002 \log C W$ & 0.978 & 0.19 & 0 & - & - \\
\hline \multirow{4}{*}{ CW vs. AW } & $\mathrm{J} \mathrm{M}$ & 65 & $\log A W=-0.262+0.700 \log C W$ & 0.679 & $4.95^{*}$ & - & - & - \\
\hline & A M & 181 & $\log A W=-0.380+0.847 \log C W$ & 0.818 & 0.51 & 0 & - & - \\
\hline & $\mathrm{J} F$ & 36 & $\log A W=-0.625+1.284 \log C W$ & 0.643 & 1.73 & 0 & $5.94 *$ & $6.50 \mathrm{~mm}$ \\
\hline & A F & 231 & $\log A W=-0.910+1.641 \log C W$ & 0.966 & $31.75^{*}$ & + & - & - \\
\hline \multirow{3}{*}{ CW vs. PL } & $\mathrm{J} \mathrm{M}$ & 78 & $\operatorname{LogPL}=-0.690+1.689 \log C W$ & 0.920 & 1.21 & 0 & $15.44 *$ & $8.8 \mathrm{~mm}$ \\
\hline & A M & 237 & $\log P L=-0.986+2.002 \log C W$ & 0.947 & $3.26^{*}$ & + & - & - \\
\hline & $\mathrm{J} / \mathrm{A} \mathrm{F}$ & 221 & $\log P L=-0.316+0.924 \log C W$ & 0.936 & $4.81^{*}$ & - & - & - \\
\hline \multirow{3}{*}{$\mathrm{CW}$ vs. $\mathrm{PH}$} & $\mathrm{J} \mathrm{M}$ & 66 & $\operatorname{LogPH}=-1.106+1.803 \log C W$ & 0.945 & 1.48 & 0 & - & - \\
\hline & A M & 188 & $\operatorname{LogPH}=-0.880+1.544 \log C W$ & 0.932 & 1.78 & 0 & - & - \\
\hline & $\mathrm{J} / \mathrm{A} \mathrm{F}$ & 224 & $\operatorname{LogPH}=-0.738+0.848 \log \mathrm{CW}$ & 0.886 & 0.74 & 0 & - & - \\
\hline \multirow{2}{*}{$\mathrm{CW} v s . \mathrm{GL}$} & $\mathrm{J} M$ & 66 & $\mathrm{LogGL}=-0.682+1.320 \log \mathrm{CW}$ & 0.838 & $0.44 *$ & 0 & - & - \\
\hline & A M & 183 & $\log G L=-0.417+1.011 \log C W$ & 0.816 & $0.03 *$ & 0 & - & - \\
\hline
\end{tabular}


(PÉREZ, 1929). Such changes are typically associated to transformations of the endocrine system, which are also related to reproductive maturation process distinguishing juvenile from adult phasis (Teissier, 1960; Hartnoll, 1982). The differences in the relative growth proceeding from the puberty molt are evidenced in the carapace dimensions, as a consequence of the gonads development. Such fact was previously observed to other brachyurans (Haley, 1972; Huber, 1985; NegreirosFrANSOZO et al., 2002, 2003). The overall mean size of adult crabs in a certain population can be result from environmental alterations as photoperiod, temperature, pluviosity, food availability, and others (CAMPBELL \& EAGLES, 1983).

Variations in the molt increment or in the molt number which occur before the puberty molt affect the crabs growth and, consequently, they can influence the size at onset of the sexual maturity. The larger body size at the sexual maturity presented by $U$. burgersi males when compared to females, despite of the analyzed site, was also observed for other Ocypodid crabs (FRITH \& BrunenMeister, 1983; Alberto \& Fontoura, 1999; Colpo \& N.-Fransozo, 2003; Costa \& N.-Fransozo, 2003). The difference in the size of the sexual maturity between sexes has been considered as caused by the changes in the growth rate in males. Frequently the lower growth rate observed in females is attributed to the fact of their energy is spent in the reproductive process (WARNER, 1967; Christy \& Salmon, 1984; Conan, 1985; Díaz \& Conde, 1989).

Males of fiddler crabs present one of the chelipeds very large, while females have both chelipeds symmetrical and very small. The growth of the fiddler crabs body part is remarkable allometric, i. e., the ratio between body parts have great differences (FRITH \& BRUNENMEISTER, 1983). Uca burgersi presented a positive allometry for both studied sites concerning to the relationship pointed by CRANE (1975), i. e., size of major cheliped and carapace width. Observations in the natural ecosystem have revealed that the major cheliped of the males can take a role, in the cohort and mating displays, beyond in the territory defense. The differences verified in the allometry of $U$. burgersi can be associated to such behavior (Christy, 1978, 1983; Christy \& SAlmon, 1984; Zucker, 1986; Murai et al., 1987; SALMON, 1987; Goshima et al., 1996; Latruffe et al., 1999; B ACKwell et. al., 2000; Pope, 2000). The positive allometry for the relationship CW vs. AW observed in adult females of $U$. burgersi was also verified in other brachyuran species (Pinheiro \& Fransozo, 1993; Mantelatto \& Fransozo, 1994, 1999; SANTOS et al., 1995; FloRES \& N.-Fransozo, 1999; N.FrAnsozo et al., 2002, 2003). After reaching the sexual morphological maturity, the abdomen becomes wider, protecting gonopores and the egg masses during incubation (HARTNOLL, 1982). The positive allometry registered for the female abdomen can be an advantage as its increasing promotes a better incubation condition for the new generation (Lewis, 1977; HAEFNER, 1990; Pinheiro \& Fransozo, 1993; Mantelatto \& Fransozo, 1994).

Acknowledgments. To FAPESP (94/4878-8; 98/031346) and $\mathrm{CNPq}$ for the financial support. To NEBECC members for help during field works and to Fúlvio A. Freire for his help in the map art.

\section{REFERENCES}

Alberto, R. M. F. \& Fontoura, N. F. 1999. Distribuição e estrutura etária de Ocypode quadrata (Fabricius, 1787) (Crustacea, Decapoda, Ocypodidae) em praia arenosa do litoral sul do Brasil. Revista Brasileira de Biologia, São Carlos, 59(1):95-108.

Backwell, P. R. Y.; Christy, J. H. et al. 2000. Dishonest signaling by a fiddler crab. Proceedings of the Royal Society of London, London, 267(B):1-6.

Campbell, A. \& Eagles, M. D. 1983. Size at maturity and fecundity of rock crab, Cancer irroratus, from the Bay of Fundy and southwestern Nova Scotia. Fishery Bulletin, Pittsburg, 81(2):357-362.

Christy, J. H. 1978. Adaptive significance of reproductive cycles in the fiddler crab Uca pugilator: a hypothesis. Science, Washington, 199:453-455.

1983. Female choice in the resource-defense mating system of the sand fiddler crab Uca pugilator. Behavioral Ecology and Sociobiology, New York, 12:169-180.

Christy, J. H. \& Salmon, M. 1984. Ecology and evolution of mating systems of fiddler crabs (genus Uca). Biological Reviews, Cambridge, 59:483-509.

Colpo, K. D. \& Negreiros-Fransozo, M. L. 2003. Reproductive output of Uca vocator (Herbst, 1804) (Brachyura, Ocypodidae) from three subtropical mangroves. Crustaceana, Leiden, 76(1): $1-11$

Conan, G. Y. 1985. Periodicity and phasing of molting. In: Wenner, A. M. Factors in adult growth. Rotterdam, A. A. Balkema. p.73-100.

Costa, T. M. \& Negreiros-Fransozo, M. L. 2003. Population biology of Uca thayeri Rathbun, 1900 (Brachyura, Ocypodidae) in a subtropical South American mangrove area: results from transect and catch per unit effort techniques. Crustaceana, Leiden, 75(10):1201-1218.

Crane, J. 1975. Fiddler crabs of the world Ocypodidae: genus Uca. New Jersey, Princeton University. 736p.

Díaz, H. \& Conde, J. E. 1989. Population dynamics and life history of the mangrove crab Aratus pisonii (Brachyura, Grapsidae) in a marine environment. Bulletin of Marine Science, Miami, 45(1):14-163.

Flores, A. A. V. \& Negreiros-Fransozo, M. L. 1999. On the population biology of the mottled shore crab Pachygrapsus transversus (Gibbes, 1850) (Brachyura, Grapsidae) in a subtropical area. Bulletin of Marine Science, Miami, 65(1):59-73

Frith, D. W. \& Brunenmeister, S. 1983. Fiddler crab (Ocypodidae: genus $U c a$ ) size, allometry and male major chela handedness and morphism on a Thailand mangrove Shore Punket Marine Biological Center. Research Bulletin, New York, 29:1-16.

GibBs, P. E. 1974. Notes on Uca burgersi from Barbuda, Leeward Islands. Crustaceana, Leiden, 27:84-91.

Gibbs, P. E. \& Bryan, G. W. 1972. A study of strontium, magnesium, and calcium in the environment and exoeskeleton of decapod crustaceans, with special reference to Uca burgersi on Barbuda, West Indies. Journal of Experimental Marine Biology and Ecology, Amsterdan, 9:97-110.

Gore, R. H. \& Scotto, L. L. 1983. Studies on decapod Crustacea from the Indian river region of Florida, XXV carapacial and abdominal allometry in five species of subtropical parthenopid crabs (Brachyura, Parthenopidea). Crustaceana, Leiden, 44(1): 1-22.

Goshima, S.; Koga, T. \& Murai, M. 1996. Mate acceptance and guarding by male fiddler crab Uca tetragonon (Herbst). Journal of Experimental Marine Biology and Ecology, Amsterdan, 196:131-143.

HAEFNER, J. A., JR. 1990. Morphometry and size at maturity of Callinectes ornatus (Brachyura, Portunidae) in Bermuda. Bulletin of Marine Science, Miami, 46(2):274-286.

Haley, S. R. 1972. Reproductive cycling in the ghost crab, Ocypode quadrata (Fabr.) (Brachyura, Oypodidae). Crustaceana, Leiden, 23:1-11. 
Hartnoll, R. G. 1974. Variation in growth pattern between some secondary sexual characters in crabs (Decapoda, Brachyura). Crustaceana,Leiden, 27(2):151-156.

1978. The determination of relative growth in Crustacea. Crustaceana, Leiden, 34(3): 281-293.

1982. Growth. In: Bliss, D. E. ed. The biology of Crustacea: embryology, morphology and genetics. New York, Academic. v.2, p.11-196.

1985. Growth, sexual maturity and reproductive output. Crustacean Issues, Amsterdam, 3:101-128.

Hines, A. H. 1989. Geographic variation in size at maturity in brachyuran crabs. Bulletin of Marine Science, Miami, 45(2):356-368.

Huber, M. E. 1985. Allometric growth of the carapace in Trapezia (Brachyura, Xanthidae). Journal of Crustacean Biology, Kansas, 5:79-83.

HuXley, J. S. 1950. Relative growth and form transformation. Proceedings of the Royal Society of London, London, 137(B):465-469.

Huxley, J. S. \& Richards, O. W. 1931. Relative growth of the abdomen and the carapace of the shore-crab Carcinus maenas. Journal of Marine Biology, Cambridge, 17:10011015.

Latruffe, C.; McGregor, P. K. \& Oliveira, R. F. 1999. Visual signaling and sexual selection in male fiddler crabs Uca tangeri. Marine Ecolology, Oldendorf, 189:233-240.

Lewis, E. G. 1977. Relative growth and sexual maturity of Bathynectes superbus (Costa) (Decapoda: Portunidae). Journal of Natural History, London, 11:629-643.

Mantelatto, F. L. M. \& Fransozo, A. 1994. Crescimento relativo e dimorfismo sexual em Hepatus pudibundus (Herbst, 1785) (Decapoda, Brachyura) no litoral norte paulista. Papéis Avulsos de Zoologia, São Paulo, 39(4):33-48.

1999. Relative growth of the crab Sesarma rectum Randall, 1840 (Decapoda, Brachyura, Grapsidae) from Bertioga, São Paulo, Brazil. Journal of Marine Biology, Cambridge, 5(1):11-21.

Melo, G. A. S. 1996. Manual de identificação dos Brachyura (caranguejos e siris) do litoral brasileiro. São Paulo, Plêiade. 604p.

Murai, M.; Goshima, S. \& Henmy, Y. 1987. Analysis of the mating system of the fiddler crab Uca lactea. Animal Behavior, London, 35:1334-1342.

Negreiros-Fransozo, M. L. 2002. Size variation in the grapsid crab Aratus pisonii (H. Milne-Edwards, 1837) among populations from different subtropical mangroves. In: Escobar-Briones, E. \& Alvarez, F. Modern approaches to the study of Crustacea. New York, Kluwer Academic. p.183-188.

Negreiros-Fransozo, M. L.; Colpo, K. D. \& Costa, T. M. 2003. Allometric growth in the fiddler crab Uca thayeri (Rathbun, 1900) (Brachyura, Ocypodidae) from a subtropical mangrove. Journal of Crustacean Biology, Kansas, 23(2):273-279.

Negreiros-Fransozo, M. L. \& Fransozo, A. 1991. Growth and age of the three juvenile crab species (Crustacea, Decapoda, Brachyura). Papéis Avulsos de Zoologia, São Paulo, 37(18):277-283.
Negreiros-Fransozo, M. L.; Fransozo, A. \& Bertini, G. 2002. Reproductive cycle and recruitment period of Ocypode quadrata (Decapoda: Ocypodidae) at a sandy beach in southeastern Brazil. Journal of Crustacean Biology, Kansas, 22(1):157-161.

Pérez, C. 1929. Sur l'appareil d'accrochage de l'abdomen au thorax chez les decapodes brachyoures. Comptès Rendús, Paris, 186:461-463.

Pinheiro, M. A. A. \& Fransozo, A. 1993. Relative growth of the speckled swimming crab Arenaeus cribrarius (Lamarck, 1818) (Brachyura, Portunidae), near Ubatuba, State of São Paulo, Brazil. Crustaceana, Leiden, 65(3):377-389.

Pope, D. S. 2000. Testing function of fiddler crab claw waving by manipulating social context. Behavioral Ecology and Sociobiology, Heidelberg, 47:432-437.

SAlmon, M. 1987. On the reproductive behavior of the fiddler crab Uca thayeri, with comparisons the $U$. pugilator and $U$. vocans: evidence for behavioral convergence. Journal of Crustacean Biology, Kansas, 7:25-44.

Santos, S.; Negreiros-Fransozo, M. L. \& Fransozo, A. 1995. Morphometric relationships and maturation in Portunus spinimanus Latreille, 1819 (Crustacea, Brachyura, Portunidae). Revista Brasileira de Biologia, São Carlos, 55(4):545-553.

Sokal, R. R. \& Rohlf, F. J. 1979. Biometry. 3. ed. New York, Freeman. $776 \mathrm{p}$.

Somerton, D. 1980. A computer technique for estimating the size of sexual maturity in crabs. Canadian Journal of Fisheries and Aquatic Sciences, Ottawa, 37:1488-1494.

Teissier, G. 1933. Étude de la croissance de quelques variantes sexuels chez Macropodia rostrata. Biological Bulletin, Carlisle, 64(4):401-444.

. 1960. Relative growth. In: Watermann, T. H. The physiology of Crustacea. New York, Academic. v.1, p. 537-560.

Thurman II, C. L. 1987. Fiddler crabs (genus Uca) of eastern Mexico (Decapoda, Brachyura, Ocypodidae). Crustaceana, Leiden, 53(1):94-105.

VAnNini, M. \& Gherardi, F. 1988. Studies on the pebble crab, Eriphia smithi Mac Leay 1938 (Xanthidae, Menippidae): patterns of relative growth and population structure. Tropical Zoology, Bangladesh, 1:203-216.

WARnER, G. F. 1967. The life history of the mangrove tree crab, Aratus pisonii. Journal of Zoology, London, 153:321-335.

Wenner, A. M.; Fusaro, C. \& Daten, A. 1974. Size at onset of sexual maturity and growth rate in crustacean populations. Journal of Zoology, London, 52(9):1095-1106.

Weymouth, F. W. \& Mackay, D. C. G. 1934. Relative growth in the edible crab Cancer magister. Proceedings of the Society for Experimental Biology and Medicine, Oxford, 31(9): 1137-1139.

1936. Analysis of the relative growth of the pacific crab Cancer magister. Proceedings of the Zoological Society of London, London, 66:257-280.

ZAR, J. H. 1996. Biostatistical analysis. Upper Saddle River, Prentice-Hall. 662p.

ZuCKer, N. 1986. On courtship patterns and the size at which male fiddler crabs (genus Uca) begin to court. Bulletin of Marine Science, Miami, 38(28):384-388. 